\title{
Splenopathy in Patients with Sickle Cell Disease
}

\begin{abstract}
Splenopathy with sickle cell disease refers to disorders that require medical care and surgical treatment. It is common in patients with sickle cell disease. The genotype of patients with sickle cell disease could affect the characteristics of splenopathy. Patients with sickle cell anemia genotype mainly experience auto-splenectomy, while those with sickle cell thalassemia have splenomegaly. Splenopathy requires careful observations by the hematologists and surgeons, especially in emergencies as it could prove fatal. Splenic infarction is the main reason for splenopathy in patients with sickle cell disease; however, it does not explain the unresolved important clinical issues. Research is still going on to explore more about the relationships between sickle cell hemoglobinopathy and splenopathy.
\end{abstract}

\section{Introduction}

Splenopathy refers to inflammatory, neoplastic, or traumatic anomalies of the spleen, and is a major complication of sickle cell disease (SCD) [1]. SCD refers to a group of inherited hematological disorders that affect different races across the geographical areas worldwide [2]. It is an autosomal recessive disorder of the beta ( $\beta$ )hemoglobin chain. In normal adults, there are two alpha $(\alpha)$ and two $\beta$ globin chains in hemoglobin A; however, in patients with SCD, a mutation in the $\beta$ globin chain leads to sickle cell hemoglobin (HbS) [3]. This mutation was first discovered by Linus Pauling in 1949. $\mathrm{He}$ proved that this abnormal hemoglobin molecule causes detrimental pathology [4]. Normally, there are three different types of hemoglobin $\mathrm{A}, \mathrm{A} 2$, and $\mathrm{F}$. $\mathrm{HbS}$ in patients with SCD contains an abnormal $\beta$ globin chain encoded by a substitution in chromosome 11 genes that result in valine instead of glutamic acid. $\alpha$-Thalassemia (Th $\alpha$ ) represents an autosomal recessive disorder with reduced production or absence of $\alpha$-globin chains that result in anemia. $\beta$-thalassemia $(\operatorname{Th} \beta)$ represents an autosomal recessive disorder with reduced production or absence of $\beta$-globin chains that also results in anemia. The main genotypes in patients with SCD are (1) homozygous HbSS sickle cell anemia (SCA) and (2) sickle cell thalassemia (SCTh) [5,6]. Further, SCTh includes either SC-Tha or SC-Th $\beta$.

The genotype of SCD determines the size of the spleen [7]. In childhood, a patient with SCA has splenomegaly; however, in adulthood the patient has spleen atrophy [8]. In SCTh, the spleen progressively increases in size, which could require splenectomy in adulthood. There are many theories about how the deformed red blood cells (RBC) containing HbS cause the clinical manifestations of SCD. Traditionally, it has been considered that the distortion of the diseased RBC causes sickling crises. This distortion is precipitated by states of low oxygen tension including dehydration, surgery, trauma, physiological or pathological stresses and temperature extremes. Because of RBC deformity, blood viscosity increases leading to disruption of blood flow, consequent vascular obstruction, and even necrosis of the end organs [9]. Such affected organs can cause numerous systemic complications including body pain syndrome, neurological, pulmonary, ophthalmological, hepatobiliary, renal,
Journal of Surgery

\author{
Hassan A. Al-Jafar ${ }^{*}$, Sulaiman Almazeedi ${ }^{2}$ and \\ Saleh Bubishate ${ }^{2}$
}

${ }^{\prime}$ Consultant hematologist, Amiri Hospital, Kuwait City, Kuwait ${ }^{2}$ Department of Surgery, Adan Hospital, Kuwait

\section{*Address for Correspondence}

Hassan A. Al-Jafar, Consultant hematologist, Amiri Hospital, Kuwait City, Kuwait, E-mail: cbc9@hotmail.com

Submission: 22 November 2015

Accepted: 09 March 2016

Published: 14 March 2016

Copyright: () $2016 \mathrm{Al}-\mathrm{Jafar} \mathrm{HA}$ et al. This is an open access article distributed under the Creative Commons Attribution License, which permits unrestricted use, distribution, and reproduction in any medium, provided the original work is properly cited.

Reviewed \& Approved by: Dr. Michael F Daily, Renal and Pancreas Transplantationan, University of Kentucky, USA

genitourinary, musculoskeletal, and many other complications including splenic diseases [10]. New evidence shows that the pathogenesis of SCD is more complicated and is not limited to a simple distortion of the RBC and vascular occlusion. Such factors are related to the other hemoglobin variants along with $\mathrm{HbS}$, which reduce polymerization potential and response to oxygen stress; moreover, they alter membrane lipids and adhesion molecules [11]. The spleen is one of the most commonly affected organs [12]. A wide spectrum of diseases can affect the spleen secondary to SCD, with new evidence surrounding their management, both medical and surgical. This article aims to review the recent literature regarding these important complications and their management.

\section{Splenic Infarction}

The repeated vaso-occlusive attacks in SCA can result in splenic infarction. Usually these infarcts are small and recurrent, resulting in subsequent auto-splenectomy [13]. In majority of the cases, the splenic infarcts are mild and self-limited. In a few cases, however, the infarcts can be severe and can result in acute splenic syndrome. In such cases, patients experience a triad of severe abdominal pain, splenomegaly, and left upper quadrant tenderness. Additionally, the patients can exhibit signs of peritonitis, guarding, abdominal rigidity as well as left pleural effusion and atelectasis. Most of these patients can be managed conservatively with proper hydration, pain control, oxygenation, and rest. However, splenic rupture may occur in severe acute splenic syndrome necessitating surgical splenectomy [14].

\section{Hyposplenism and Functional Asplenia}

Hyposplenism and functional asplenia are well-recognized complications of SCA and are characterized by impaired and loss of the reticuloendothelial function of the spleen, respectively [15]. This dysfunction is considered to be a consequence of splenic fibrosis caused by repeated vascular occlusion and infarction [16]. Hyposplenism can also result secondary to the surgical removal of the spleen following therapeutic splenic immobilization and as a complication of certain medical conditions [17]. The diagnosis of hyposplenism does not always correlate with a decrease in the spleen size per se; rather it has been shown to be related to decrease splenic 
vascularization. This condition can be diagnosed by assessing the filtering function of the spleen, as measured by the levels of the HowelJolly bodies in RBCs as well as by nuclear imaging [18]. Patients with hyposplenism and/or functional asplenia are at an increased risk of infection due to "impaired immunity [17]. These patients are particularly susceptible to infection by encapsulated bacteria, especially Streptococcus pneumonia, Neisseria meningitides, and Haemophilus influenzae. In addition, other factors have been found that predispose a patient to this overwhelming infection. These include dysfunction of immunoglobulin IgG and IgM response, defects in the alternative pathway of the complement system, and dysfunction of phagocytic opsonization $[19,20]$. The prevention of such infections is best achieved by proper immunization, antibiotic prophylaxis, and optimal patient education [21].

\section{Acute Splenic Sequestration}

Acute splenic sequestration is a life-threatening event and is a leading cause of deaths in children with SCD [22]. In patients, who are homozygous for HbSS, the incidence of acute splenic sequestration is reported to be between $7 \%$ and $30 \%$. It can occur as early as 8 weeks of age with $76 \%$ of the cases as less than 2 years of age $[23,24]$. The pathophysiology remains unclear. However, it has been suggested that the diversion of the blood flow through the intrasplenic shunt causes splenomegaly, RBC retention, and capillary engorgement. Patients usually experience signs of hypovolemic shock, and a decrease of $2 \mathrm{~g} / \mathrm{dL}$ or more is observed in their normal blood hemoglobin concentration along with evidence of reticulocytosis [2325]. This condition can deteriorate and lead to death, if not treated adequately. Treatment of acute splenic sequestration mainly consists of early diagnosis, clinical support, and packed RBC transfusion [24]. In patients who survive an attack, subsequent splenectomy is usually performed to avoid the potentially life-threatening complications of recurrence $[25,26]$.

\section{Splenomegaly}

Splenomegaly is a characteristic feature of SCTh. Splenomegaly occurs because of occlusion of the venules and sinusoids of the spleen due to trapping of sickled RBCs $[27,28]$. It usually occurs at 6 months of age and remains enlarged [29]. Splenic size is normally $<12 \mathrm{~cm}$; the moderately enlarged spleens are $12-20 \mathrm{~cm}$ in size, and the severely enlarged spleens are $>20 \mathrm{~cm}$ in size. Special attention should be given to spleens $>20 \mathrm{~cm}$ in size, which are considered to be giant-sized spleens and are really difficult to remove laparoscopically because of limitations in instrumentation and visualization [30]. Recent studies have shown that the treatment of symptomatic splenomegaly with splenectomy is safe and beneficial in patients with SCD [31]. SCA may combine, notably in infancy, with functional hyposplenism and splenomegaly. At birth, the spleen in SCA is morphologically and functionally normal. Progressive injury occurs when the hemoglobin switch initiates the multiple changes in the sickle RBC adherence and signaling properties [27]. Splenomegaly may be associated with an overactive spleen (hypersplenism), a condition that can develop because too many blood cells build up and are destroyed within the spleen. Hypersplenism can contribute to anemia in individuals with SCTh and can lead to low levels of the white blood cells and platelets; hence, the risk of infection increases [32].

\section{Splenic Abscess}

Splenic abscess is a very rare condition that affects patients with SCD and is associated with a high mortality rate [33]. About only 600 cases have been reported in the literature. These have occurred mostly in the tropics. The causes of splenic abscess include a direct extension from the infected contiguous organ, hematogenic spread from another site of the body (most commonly bacterial endocarditis), infection secondary to spleen trauma, and in the immuno-compromised [34]. Patients usually have non-specific symptoms that can make the diagnosis very difficult. Frequently the symptoms and signs include fever, abdominal pain, and upper left quadrant tenderness, splenomegaly, leukocytosis, and left lower chest clinical problems. Diagnosis can be made by performing either computed tomography or abdominal ultrasonography. There is currently no consensus regarding the cutoff for the percutaneous drainage of the abscess versus splenectomy. As a general rule, unilocular abscesses $<3 \mathrm{~cm}$ in size with thin liquid content can be safety drained under radiological guidance [33]. When abscess size is $>10 \mathrm{~cm}$ or non-surgical treatment has failed, splenectomy has been shown to be a safe alternative to treat the condition [35].

\section{Surgical Splenectomy Indications in SCD}

Certain clinical situations warrant surgical splenectomy in SCD. First, patients with acute splenic syndrome usually undergo splenectomy if their condition can be managed conservatively and splenic rupture has occurred [14]. Second, in patients who survive an acute splenic syndrome attack, subsequent splenectomy is usually performed to avoid the potentially life-threatening complications of recurrence $[25,26]$. Third, patients with symptomatic splenomegaly due to SCD are candidates for splenectomy [31]. Fourth, patients with splenic abscess can undergo splenectomy [35]. Additionally, splenectomy is performed in patients with massive splenic infarction [31].

\section{Splenectomy Prophylactic Measures}

Asplenia predisposes patients with SCD to the risks of overwhelming and life-threatening infections. The potential sepsis in patients with SCD is caused by encapsulated organisms [36]. It is, therefore, necessary for patients with asplenia and SCD to follow a strict vaccination program to prevent such overwhelming sepsis. Table 1 presents a summary of the advised protocol to follow for optimal sepsis prevention. Vaccines are recommended for adults $(>18$ years) with asplenia/hyposplenism (who have not been immunized previously).

Pre-splenectomy vaccines prophylaxes for elective splenectomy at least 2 weeks (ideally 4-6 weeks) prior to surgery; further, pneumococcal, meningococcal, Haemophilus influenzae type b, influenza, and hepatitis vaccines can be administered [37-39]. In emergency vaccination plus antibiotic injection as amoxicillin, phenoxymethylpenicillin (Penicillin V). If the patient is penicillinallergic: erythromycin or clarithromycin can be substituted.

\section{Post-Splenectomy Antibiotic Prophylaxis}

Patients should be provided with a supply of oral amoxicillin or clarithromycin if penicillin-allergic to be kept at home. If a patient does become clinically infected despite prophylactic antibiotics, he/ 
Table 1: Vaccination protocol for patients with asplenia and sickle cell disease [41-43].

\begin{tabular}{|c|c|c|c|c|c|}
\hline Vaccine & Timing & Dose & Route & Revaccination Schedule & Comments \\
\hline Polyvalent pneumococcal vaccine & & $0.5 \mathrm{~mL}$ & SC & After every 5 years & $\begin{array}{l}\text { Immunity may decline } \\
\text { rapidly in certain patient } \\
\text { groups. }\end{array}$ \\
\hline $\begin{array}{l}\text { Tetravalent meningococcal } \\
\text { polysaccharide vaccine }\end{array}$ & $\begin{array}{l}\text { Administer at least } \\
2 \text { weeks prior to } \\
\text { splenectomy if possible, or } \\
2 \text { weeks after splenectomy }\end{array}$ & $0.5 \mathrm{~mL}$ & SC & After every 5 years & $\begin{array}{l}\text { Used in previously } \\
\text { unvaccinated individuals }\end{array}$ \\
\hline $\begin{array}{l}\text { Haemophilus influenzae } \\
\text { type b conjugate vaccine }\end{array}$ & & $0.5 \mathrm{~mL}$ & $\begin{array}{l}\mathrm{IM} \\
\text { in the deltoid } \\
\text { region }\end{array}$ & None & \\
\hline Influenza vaccine & $\begin{array}{l}\text { Administer as soon as } \\
\text { practicable before or after } \\
\text { splenectomy, to ensure } \\
\text { seasonal protection }\end{array}$ & $0.5 \mathrm{~mL}$ & $\begin{array}{l}\text { IM } \\
\text { in the deltoid } \\
\text { region }\end{array}$ & Yearly & $\begin{array}{l}\text { Administered preferably in } \\
\text { October }\end{array}$ \\
\hline Hepatitis B vaccine & & $1 \mathrm{~mL}$ & $\begin{array}{l}\mathrm{IM} \\
\text { in the deltoid } \\
\text { region }\end{array}$ & $\begin{array}{l}\text { At } 0,1 \text {, and } 6 \text { months that provide } \\
\text { optimal protection at the seventh } \\
\text { month. }\end{array}$ & $\begin{array}{l}\text { Administered because } \\
\text { SCD could require blood } \\
\text { transfusions }\end{array}$ \\
\hline
\end{tabular}

1-Malaria prophylaxis is indicated when a patient is travelling to a malaria-endemic area [44].

2-Immediate reporting after animal bites is indicated [45].

she should immediately start a therapeutic course of antibiotics and seek urgent medical attention, as hospital admission may be required [36]. Some guidelines advise prophylactic antibiotics for the first 3-5 years after splenectomy; however, data indicate that the risk of overwhelming post-splenectomy infection does not decline with time. Unfortunately, long-term antibiotic therapy is a risk factor for selection of resistant strains, and antibiotic efficacy may reduce by non-compliance. Thus, the decision of whether to administer prophylactic antibiotics or not depends largely on the patient and the physician's preference. The choice of antibiotics is also controversial. Penicillin would provide prophylaxis only against sensitive pneumococci, meningococci, and streptococci; however, it is suitable for adults at a dose of $500 \mathrm{mg}$ daily or twice a day. Amoxicillin would be a preferred choice in children. In penicillin-allergic individuals, alternatives are either co-trimoxazole or a fluoroquinolone with Gram-positive activity such as moxifloxacin [40].

\section{References}

1. Srp A, Bruna J (1989) Computed tomography of the spleen. Acta Univ Caro Med (Praha) 35: 11-30.

2. Afolayan JA, Jolayemi FT (2011) Parental attitude to children with sickle cell disease in selected health facilities in Irepodun Local Government, Kwara State, Nigeria. Ethno Med 5: 33-40.

3. Haig M (2007) Managing the pain of sickle cell anemia. Anesthesiology Rounds 6.

4. Odièvre $\mathrm{MH}$, Verger E, Silva-Pinto AC, Elion J (2011) Pathophysiological insights in sickle cell disease. Indian J Med Res 134: 532-537.

5. Bowden DK (2001) Screening for thalassaemia. Aust Prescr 24: 120-123.

6. Pearson HA, Gallagher D, Chilcote R, Sullivan E, Wilimas J, et. al. (1985)
Developmental pattern of splenic dysfunction in sickle cell disorders. Pediatrics 76: 392-397.

7. Eze CU, Offordile GC, Agwuna KK, Ocheni S, Nwadike IU, et al. (2015) Sonographic evaluation of the spleen among sickle cell disease patients in a teaching hospital in Nigeria. African Health Sci 15: 949-958.

8. Al-Salem AH (2011) Splenic complications of sickle cell anemia and the role of splenectomy. ISRN Hematol 2011: 864257.

9. Green MD (2003) Sickle cell disease a behavioral approach to a systemic disease. J Behav Optom 14: 1-3.

10. Ballas SK, Kesen MR, Goldberg MF, Lutty GA, Dampier C, et al. (2012) Beyond the definitions of the phenotypic complications of sickle cell disease: an update on management. ScientificWorldJournal 2012: 949535.

11. Makani J, Ofori-Acquah SF, Nnodu O, Wonkam A, Ohene-Frempong K (2013) Sickle cell disease: new opportunities and challenges in Africa. ScientificWorldJournal 2013: 193252.

12. Al-Salem AH (2011) Splenic complications of sickle cell anemia and the role of splenectomy.

13. Jama AH, Salem AH, Dabbous IA (2002) Massive splenic infarction in Saud patients with sickle cell anemia: a unique manifestation. Am J Hematol 69: 205-209.

14. Tsaras G, Owusu-Ansah A, Boateng FO, Amoateng-Adjepong Y (2009) Complications associated with sickle cell trait: a brief narrative review. Am J Med 122: 507-512.

15. Babadoko AA, Ibinaye PO, Hassan A, Yusuf R, ljei IP, et al. (2012) Autosplenectomy of sickle cell disease in zaria, Nigeria: an ultrasonographic assessment. Oman Med J 27: 121-123.

16. Harris KB (2002) Guidelines for the treatment of people with sickle cel disease. Written by members of SCAC (the Sickle Cell Advisory Committee) of GENES (The Genetic Network of New York, Puerto Rico, and the Virgin Islands) with the support from grants from HRSA. 
17. Davies JM, Lewis MP, Wimperis J, Rafi I, Ladhani S, et al. (2011) Review of guidelines for the prevention and treatment of infection in patients with an absent or dysfunctional spleen: prepared on behalf of the British Committee for Standards in Haematology by a working party of the Haemato-Oncology task force. Br J Haematol 155: 308-317.

18. Benter T, Klühs L, Teichgräber U (2011) Sonography of the spleen. J Ultrasound Med 30: 1281-1293

19. Bjornson AB, Lobel JS (1987) Direct evidence that decreased serum opsonization of Streptococcus pneumonia via the alternative complement pathway in sickle cell disease is related to antibody deficiency. J Clin Invest 79: 388-398

20. Overturf GD (1999) Infections and immunizations of children with sickle cell disease. Adv Pediatr Infect Dis 14: 191-218.

21. Elmakki E (2012) Hypersplenism: Review article. J Biol Agric Healthc 2.

22. Sandoval C, Stringel G, Ozkaynak MF, Tugal O, Jayabose S (2002) Perioperative management in children with sickle cell disease undergoing laparoscopic surgery. JSLS 6: 29-33.

23. Ballas SK, Lieff S, Benjamin LJ, Dampier CD, Heeney MM, et al. (2010) Definitions of the phenotypic manifestations of sickle cell disease. Am J Hematol 85: 6-13.

24. Rezende PV, Viana MB, Murao M, Chaves AC, Ribeiro AC (2009) Acute splenic sequestration in a cohort of children with sickle cell anemia. J Pediatr (Rio J) 85: 163-169.

25. Owusu-Ofori S, Hirst C (2013) Splenectomy versus conservative managemen for acute sequestration crises in people with sickle cell disease. Cochrane Database Syst Rev 5: CD003425.

26. Maia CB, Nomura RM, Igai AM, Fonseca GH, Gualandro SM, et al. (2013) Acute splenic sequestration in a pregnant woman with homozygous sicklecell anemia. Sao Paulo Med J 131: 123-126.

27. Brousse V, Buffet $P$, Rees D (2014) The spleen and sickle cell disease: the sick(led) spleen. Br J Haematol 166: 165-176.

28. Chopra R, Al-Mulhim AR, Al-Baharani AT (2005) Fibrocongestive splenomegaly in sickle cell disease: a distinct clinicopathological entity in the Eastern province of Saudi Arabia. Am J Hematol 79: 180-186.

29. Parmar D, Likhar KS (2014) Prevalence of splenomegaly in sickle cell anemia patients in relation to Hemoglobin F. IJRRMS 4: 12-15.

30. Muzhir K, Albudairy HA (2015) Concomitant laparoscopic cholecystectomy and laproscopic assisted splenectomy for surgical management of hereditary spherocytosis. Wasit J Sci Med 8: 82 -88.

31. Al-Salem $\mathrm{AH}$ (2006) Indications and complications of splenectomy for children with sickle cell disease. J Pediatr Surg 41: 1909-1915.

32. NORD (2015) Beta thalassemia. National Organization for Rare Disorders.

33. Maliyil J, Caire W, Nair R, Bridges D (2011) Splenic abscess and multiple brain abscesses caused by Streptococcus intermedius in a young healthy man. Proc (Bayl Univ Med Cent) 24: 195-199.

34. Jaiswal SS, Talreja M, Chawla B, Chitkara G, Beedkar S (2014) Organ preservation in splenic abscess. Med J Armed Forces India 70: 195-197.

35. Alvi AR, Kulsoom S, Shamsi G (2008) Splenic abscess: outcome and prognostic factors. J Coll Physicians Surg Pak 18: 740-743.

36. Di Sabatino A, Carsetti R, Corazza GR (2011) Post-splenectomy and hyposplenic states. Lancet 378: 86-97.

37. Landgren O, Bjoerkholm M, Konradsen HB, Söderqvist M, Nilsson B, et al. (2004) A prospective study on antibody response to repeated vaccinations with pneumococcal capsular polysaccharide in splenectomized individuals with special reference to Hodgkin's lymphoma. J Intern Med 255: 664-673.

38. Shatz DV, Romero-Steiner S, Elie CM, Holder PF, Carlone GM (2002) Antibody responses in postsplenectomy trauma patients receiving the 23-valent pneumococcal polysaccharide vaccine at 14 versus 28 days postoperatively. J Trauma 53: 1037-1042.

39. ORMC (2006) Post-splenectomy vaccine prophylaxis. Department of Surgical Education, Orlando Regional Medical Center.

40. Davidson RN, Wall RA (2001) Prevention and management of infections in patients without a spleen. Clin Microbiol Infect 7: 657-660.

41. Musher DM, Bartlett JG, Thorner AR (2016) Pneumococcal vaccination in adults. UpToDate, Inc.

42. eMC (2015) Engerix B 20 micrograms/1 ml Suspension for injection in prefilled syringe.

43. Kaddah N, Kaddah A, Omar N, Mostafa A (2010) Antibody response to hepatitis $b$ immunization in Egyptian children with sickle cell disease. Egypt $J$ Pediatr Allergy Immunol 8: 67-73.

44. (2015) Infectious diseases related to travel. Centers for Disease Control and Prevention.

45. Moore DA, Sischo WM, Hunter A, Miles T (2000) Animal bite epidemiology and surveillance for rabies postexposure prophylaxis. J AM Vet Med Assoc 217: 190-194.

\section{Acknowledgement}

Our grateful to Kuwait Foundation for the advancement of science ( KFAS ), for funding partially this sickle cell disease Project under code: P116 - 13MM-01. 